\title{
Penerimaan Keluarga Dalam Perawatan Orang Dengan Skizofrenia Di Masyarakat Banjar Kalimantan Selatan
}

\author{
Subhannur Rahman ${ }^{1}$, Iman Permana ${ }^{2}$ \\ ${ }^{1,2}$ Program Studi Magister Keperawatan Universitas Muhammadiyah Yogyakarta \\ Jl. Lingkar Selatan, Tamatirto, Kasihan Bantul, DI Yogyakarta \\ * correspondence author: Handphone: 08214965 1990, Email: subhannur1990@gmail.com
}

DOI: https://doi.org/10.33859/dksm.v10i1.424

\begin{abstract}
Abstrak
Latar Belakang: Merawat anggota keluarga dengan skizofrenia merupakan hal yang tidak mudah dan harus mengalami perjalanan yang panjang terutama bagi mereka yang menjadi caregiver. Timbulnya beban dan beberapa efek buruk bagi keluarga sebagai pengasuh tentu akan mempengaruhi proses perawatan yang diberikan dan penerimaan didalam keluarga.

Tujuan: Penelitian ini bertujuan untuk mengeksplorasi penerimaan keluarga dalam perawatan orang dengan skizofrenia.

Metode: Penelitian ini adalah penelitian kualitatif dengan jenis pendekatan fenomenologi deskriptif. Pemilihan informan menggunakan metode purposive sampling yang berjumlah 7 (tujuh) informan. Pengumpulan data menggunakan metode wawancara semi-struktur.

Hasil: Hasil penelitian ini menunjukkan bahwa penerimaan keluarga dalam perawatan orang dengan skizofrenia di Masyarakat Banjar Kalimantan Selatan mendapatkan 4 (empat) tema yaitu a) belum bisa menerima, b) situasi yang sudah biasa, c) penolakan keluarga, d) bersikap pesimis.

Simpulan: Penerimaan keluarga menjadi salah satu faktor penentu dalam mencapai proses penyembuhan pada anggota keluarga yang mengalami gangguan jiwa. Bentuk penerimaan yang positif dari anggota keluarga dalam memberikan perawatan mencerminkan kesiapan keluarga untuk merawat anggota keluarga dengan skizofrenia. Walaupun keluarga sebagai caregiver memiliki perasaan yang kurang menyenangkan didalam proses perawatan yang diberikan
\end{abstract}

Kata Kunci: Penerimaan Keluarga, Perawatan Orang Dengan Skizofrenia. 
Family Acceptance in the Care of People With Schizophrenia In the Banjar Community in South Kalimantan

\begin{abstract}
Background: Caring for family members with schizophrenia is not easy and must experience a long journey, especially for those who become caregivers. The onset of the burden and some adverse effects on the family as caregivers will certainly affect the process of care given and acceptance in the family. Objective: This study aims to explore family acceptance in the care of people with schizophrenia.

Method: This study is a qualitative research with a descriptive phenomenological approach. The selection of informants used a purposive sampling method which amounted to 7 (seven) informants. Data collection uses semi-structured interview methods.

Results: The results of this study indicated that family acceptance in the care of people with schizophrenia in the Banjar Community in South Kalimantan received 4 (four) themes, namely a) unable to accept, b) usual situation, c) family rejection, d) being pessimistic.

Conclusion: Family acceptance is one of the determining factors in achieving the healing process in family members who experience mental disorders. The positive form of acceptance from family members in providing care reflects family readiness to care for family members with schizophrenia. Although the family as a caregiver has unpleasant feelings in the treatment process given
\end{abstract}

Keywords: Family Acceptance, Treatment of People with Schizophrenia.

\section{Pendahuluan}

Gangguan jiwa merupakan salah satu masalah kesehatan masyarakat diseluruh dunia. Data menunjukkan sekitar 35 juta orang mengalami depresi, 60 juta orang mengalami bipolar disorder, 47,5 juta orang mengalami demensia dan 21 juta orang mengalami skizofrenia (WHO, 2016). Kejadian skizofrenia di seluruh dunia menjadi permasalahan psikis yang bersifat serius dan menimbulkan beban besar kedua setelah penyakit jantung. Sekitar 20 juta jiwa kejadian skizofrenia banyak terjadi di negara-negara yang sedang berkembang. Di Indonesia fenomena orang dengan skizofrenia setiap tahunnya selalu mengalami peningkatan jumlah. Tercatat sebanyak $70 \%$ gangguan jiwa terbesar adalah skizofrenia dan di Kalimantan Selatan prevalensi orang dengan skizofrenia mencapai 1,4 permil yang merupakan prevalensi terbesar di wilayah Pulau Kalimantan (Mueser, et al, 2014., Sutini \& Yosep, 2016., Rohmatin, et al, 2016., 
Dinamika Kesehatan Jurnal Kebidanan dan Keperawatan Vol 10 No. 1 Juli 2019 ( ISSN: 2086-3454 EISSN: 2549-4058) url: http://ojs.dinamikakesehatan.unism.ac.id DOI: https://doi.org/10.33859/dksm.v10i1.424

Penerimaan Keluarga Dalam Perawatan Orang dengan Skizofrenia di Masyarakat Banjar Kalimantan Selatan

Widianti, et al, 2017). Skizofrenia merupakan

sekelompok gangguan otak atau penyakit

mental yang ditandai dengan adanya gejala halusinasi, delusi maupun penurunan motivasi dan afek yang tumpul (Emsley, et al, 2013., Boyer, et al, 2013., Sariah, et al, 2014., Grover, et al, 2014., Sansa, et al, 2016., Ban, et al, 2017). Fenomena permasalahan skizofrenia sampai saat ini masih menjadi salah satu permasalahan penyakit mental yang menimbulkan beban bagi keluarga sebagai pengasuhnya. Berbagai macam permasalahan yang dihadapi keluarga muncul dalam proses penerimaan anggota keluarga terhadap orang dengan skizofrenia, seperti banyaknya waktu keluarga yang terbuang didalam pekerjaan, banyaknya biaya hidup yang mereka harus keluarkan, terbatasnya waktu untuk bersosialisasi, munculnya perasaan stress, depresi, malu, perasaan bersalah dan stigma (Gupta, et al, 2015., Zhou, et al, 2016., Ayu, Candra, \& Kartika, 2019).

\section{Metode Penelitian}

Penelitian ini menggunakan metode kualitatif dengan pendekatan fenomenologi deskriptif. Penelitian ini menggunakan informan sebanyak 7 (tujuh) orang, dengan teknik pengambilan sampel purposive sampling. Kriteria informan dalam penelitian ini meliputi caregiver yang memberikan perawatan seharihari kepada orang dengan skizofrenia dan tinggal serumah bersama caregiver, caregiver yang memberikan perawatan dengan kurun waktu 1 tahun terakhir dan caregiver yang tidak memiliki riwayat gangguan jiwa sebelumnya. Penelitian ini dilakukan di wilayah kerja Puskesmas Pekauman Banjarmasin dengan waktu penelitian Januari sampai dengan Februari 2019. Data dikumpulkan dengan menggunakan teknik wawancara semi terstruktur dengan waktu selama 30 - 60 menit. Alat yang digunakan dalam proses pengumpulan data berupa catatan lapangan, alat perekam suara dan panduan wawancara. Selain itu peneliti juga melakukan uji validitas dan reabilitas dengan cara perpanjangan pengamatan, meningkatkan 
Dinamika Kesehatan Jurnal Kebidanan dan Keperawatan Vol 10 No. 1 Juli 2019 ( ISSN: 2086-3454 EISSN: 2549-4058) url: http://ojs.dinamikakesehatan.unism.ac.id DOI: https://doi.org/10.33859/dksm.v10i1.424

Penerimaan Keluarga Dalam Perawatan Orang dengan Skizofrenia di Masyarakat Banjar Kalimantan Selatan

ketekunan, melakukan triangulasi data peneliti mengelompokkan kategori tersebut menggunakan field notes berupa catatan yang serupa ke dalam sub tema dan tema, $\mathrm{f}$ ) lapangan dan member checking. Terakhir selanjutnya selama proses analisa data, peneliti peneliti juga melakukan audit data temuan merangkai tema yang ditemukan dan bersama dengan pembimbing penelitian. menuliskannya menjadi sebuah deskripsi Tahapan analisis data menggunakan Colaizzi dalam bentuk hasil penelitian.

1978 dengan beberapa tahapan sebagai berikut; a) pendeskripsian fenomena yang diteliti dengan cara mengumpulkan pernyataan dari beberapa informan, b) membaca seluruh deskripsi dari fenomena yang telah disampaikan oleh informan, c) membaca kembali transkip data dari hasil wawancara dan melakukan pengutipan beberapa pernyataan-pernyataan yang bermakna, d) menguraikan arti yang ada dalam bentuk pernyataan-pernyataan yang signifikan. Tahapan ini peneliti mencoba mengartikulasikan makna dari setiap pernyataan yang signifikan tersebut dengan memilih kata kunci untuk membentuk kategori, e) selanjutnya peneliti membaca seluruh kategori yang ada, kemudian membandingkan dan mencari persamaan diantara kategori-kategori. Pada akhirnya

\section{Hasil Penelitian}

Penelitian ini didapatkan 4 (empat) tema besar dari penerimaan keluarga dalam perawatan orang dengan skizofrenia di Masyarakat Banjar Kalimantan Selatan.

\section{Belum Bisa Menerima}

Hal ini terjadi karena adanya penyesuaian keluarga terhadap kondisi yang penuh tekanan akibat adanya anggota keluarga yang mengalami skizofrenia (Wardhani \& Asyanti, 2015., Nora, 2018). Seperti yang ditunjukkan oleh kutipan informan dibawah ini.

"Sedih sampai sekarang sebab dari saudara-saudaraku, aku rasa terkucil, kaya semuanya itu menghina anakku...'(I1).

"Kami berdua berat asalnya, tapi sambil berdoa sama Tuhan kenapa jadi anak 
Dinamika Kesehatan Jurnal Kebidanan dan Keperawatan Vol 10 No. 1 Juli 2019 ( ISSN: 2086-3454 EISSN: 2549-4058) url: http://ojs.dinamikakesehatan.unism.ac.id DOI: https://doi.org/10.33859/dksm.v10i1.424

Penerimaan Keluarga Dalam Perawatan Orang dengan Skizofrenia di Masyarakat Banjar Kalimantan Selatan

kami kaya gini, tidak di sangka toh apa

dosa kami berdua...'(I2).

2. Situasi yang sudah biasa

Caregiver sebagai orang yang bertanggung jawab dalam memberikan dukungan perawatan tentu sudah menjalani beberapa fase didalam proses penerimaan anggota keluarga dengan skizofrenia. Khususnya difase penerimaan, keluarga sebagai caregiver telah mampu untuk menerima kenyataan dan menerima keadaan anggota keluarga yang sakit dengan baik dan ihklas. Serta menjadikan agama sebagai bentuk koping yang digunakan (Dewi, 2018., Ayu, Candra, \& Kartika., 2019). Seperti yang diungkapkan oleh informan dibawah ini.

"Biasa biasa aja paham aja dengan kondisi keluarga kaya gini"...(I5).

\section{Penolakan Keluarga}

Keluarga memiliki stigma yang tinggi selama memberikan dukungan perawatan kapada orang dengan skizofrenia. Akibatnya caregiver sering mendapatkan reaksi yang negatif dari orang lain karena seperti kritikan dan diskriminasi
(Koschorke et al., 2014). Seperti yang diungkapkan informan pada kutipan dibawah ini.

"Kalau yang lain semua nembak, katanya kenapa diobati orang seperti itu, masukkan ke sana itu ke Rumah Sakit Sambang Lihum pal 17 selesai”...(I1).

"Macam-macam, ada yang mendukung ada juga yang tidak. Kami tidak senangnya itu bilang kaya gini, tidak malu kah coba bawa dan di titipkan di sambang lihum (rumah sakit jiwa)”...(I2).

4. Bersikap pesimis

Penelitian Frasia, Zuhriyah, \& Kapti (2018) mengatakan bahwa apabila keluarga memiliki sikap pesimis tentunya akan memberikan hasil yang tidak baik dan bahkan bisa menghasilkan lebih banyak perasaan negatif seperti kegelisahan, kemarahan, kesedihan bahkan dengan keputusasaan. Seperti yang diungkapkan oleh informan dibawah ini.

"Kalaunya memang usahanya dijalankan sih saya percaya ada kesempatan 
Dinamika Kesehatan Jurnal Kebidanan dan Keperawatan Vol 10 No. 1 Juli 2019 ( ISSN: 2086-3454 EISSN: 2549-4058)

url: http://ojs.dinamikakesehatan.unism.ac.id DOI: https://doi.org/10.33859/dksm.v10i1.424

Penerimaan Keluarga Dalam Perawatan Orang dengan Skizofrenia di Masyarakat Banjar Kalimantan Selatan

untuknya kembali. Tapi kalau seperti ini

masih sedikit ragu kaya gitu”...(I5).

"Kalau untuk berubah itu kan kira kira lambat lagi soalnya akalnya itu kaya anak anak masih"...(I7).

\section{Simpulan}

Penerimaan keluarga menjadi salah satu faktor penentu dalam mencapai proses penyembuhan pada anggota keluarga yang mengalami gangguan jiwa. Bentuk penerimaan yang positif dari anggota keluarga dalam memberikan perawatan mencerminkan kesiapan keluarga untuk merawat anggota keluarga dengan skizofrenia. Walaupun keluarga sebagai caregiver memiliki perasaan yang kurang menyenangkan didalam proses perawatan yang diberikan.

\section{Saran}

Sebaiknya keluarga yang berperan sebagai caregiver diberikan pengetahuan tentang bagaimana cara merawat anggota keluarga yang mengalami gangguan jiwa. Adanya bekal pengetahuan yang diberikan akan menambah motivasi dan keinginan keluarga dalam merawat serta menerima orang dengan skizofrenia.

\section{Ucapan Terima Kasih}

Saya mengucapkan terimakasih banyak kepada:

1. dr. Iman Permana., M.Kes., Ph.D, selaku dosen pembimbing yang telah memberikan masukan serta saran dalam penyusunan tesis ini.

2. Puskesmas Pekauman Kota Banjarmasin yang telah bersedia untuk memfasilitasi peneliti untuk melakukan proses penelitian.

3. Informan penelitian yang telah berpartisipasi dalam penelitian ini.

\section{Daftar Pustaka:}

Ayu, I., Candra, W., \& Kartika, Y. (2019). Proses penerimaan anggota keluarga orang dengan skizofrenia. Jurnal Psikologi Udayana, 6(1), 859-872.

Ban, C., Zhang, Q., Feng, J., Li, H., Qiu, Q., Tian, Y., \& Li, X. (2017). Low prevalence of lipid metabolism abnormalities in APOE ع2-genotype and male patients 60years or older with schizophrenia. BMC Psychiatry, 17(1), 1-8. 
https://doi.org/10.1186/s12888-0171530-9.

Boyer, L., Millier, A., Perthame, E., Aballea, S., Auquier, P., \& Toumi, M. (2013). Quality of life is predictive of relapse in schizophrenia. BMC Psychiatry, 13, $1-8$. https://doi.org/10.1186/1471-244X13-15.

Dewi, G. K. (2018). Pengalaman Caregiver Dalam Merawat Klien Skizofrenia Di Kota Sungai Penuh. Jurnal Endurance, 3(1), 200-212.

Emsley, R., Chiliza, B., Asmal, L., \& Harvey, B. H. (2013). The nature of relapse in schizophrenia. $B M C \quad$ Psychiatry, 13(1),50.https://doi.org/10.1186/1471 $-244 \mathrm{X}-13-50$.

Grover, S., Davuluri, T., \& Chakrabarti, S. (2014). Religion, spirituality, and schizophrenia: A review. Indian Journal of Psychological Medicine, 36(2), 119.

https://doi.org/10.4103/0253$\underline{7176.130962 .}$

Gupta, S., Isherwood, G., Jones, K., \& Van Impe, $\quad$ K. (2015). Assessing health status in informal schizophrenia

caregivers compared with health status in non-caregivers and caregivers of other conditions. BMC Psychiatry, 15,162.https://doi.org/10.1186/s12888 $-015-0547-1$.

Koschorke, M., Padmavati, R., Kumar, S., Cohen, A., Weiss, H.A., Chatterjee, S., Patel, V. (2014). Experiences of stigma and discrimination of people with schizophrenia in India.
Social Science and Medicine, 123, 149-159.

https://doi.org/10.1016/j.socscimed.2

$\underline{014.10 .035 .}$.

Mueser, K.T., Rosenberg, S.D., Jankowski, M.K., Bolton, E.E., Lu, W., \& Wolfe, R. (2014). NIH Public Access, 76(2), 259-271. http://doi.org/10.1037/0022006X.76.2.259.A.

Nora, R. (2018). Studi Fenomenologi : Pengalaman Keluarga Matrilinial Dalam Merawat Klien Perilaku Kekerasan Di Kota Padang. Jurnal Endurance, 3(3), 422-433.

Rohmatin, Y. K., Limantara, S., \& Arifin, S. (2016). Gambaran Kecenderungan Depresi Keluarga Pasien Skizofrenia Berdasarkan Karakteristik Demografi Dan

Psikososial. Berkala Kedokteran, 12(2), 239-253.

Sansa, G., Gavaldà, A., Gaig, C., Monreal, J., Ercilla, G., Casamitjana, R., ... Santamaria, J. (2016). Exploring the presence of narcolepsy in patients with schizophrenia. BMC Psychiatry, 16(1), 1-7. https://doi.org/10.1186/s12888-0160859-9.

Sariah, A. E., Outwater, A. H., \& Malima, K. I. (2014). Risk and protective factors for relapse among Individuals with Schizophrenia: A Qualitative Study in Dar es Salaam, Tanzania. BMC Psychiatry, 14(1), 240.

https://doi.org/10.1186/s12888-0140240-9.

Widianti, E., Keliat, B. A., \& Wardhani, I. Y. (2017). Aplikasi Terapi Spesialis Keperawatan Jiwa 
Dinamika Kesehatan Jurnal Kebidanan dan Keperawatan Vol 10 No. 1 Juli 2019 ( ISSN: 2086-3454 EISSN: 2549-4058) url: http://ojs.dinamikakesehatan.unism.ac.id DOI: https://doi.org/10.33859/dksm.v10i1.424

Penerimaan Keluarga Dalam Perawatan Orang dengan Skizofrenia di Masyarakat Banjar Kalimantan Selatan

Pada Pasien

Skizofrenia Dengan Harga Diri

Rendah Kronis Di Rsmm

Jawa Barat. Jurnal Pendidikan

Keperawatan Indonesia, 3(1), 83-99.

WHO. Mental Health. (2016).

Zhou, Y., Rosenheck, R., Mohamed, S., Ou, Y., Ning, Y., \& He,H. (2016).

Comparison of burden among family members

of patients diagnosed with schizophrenia and bipolar disorder in a large acute psychiatric hospital in China. BMC Psychiatry, 16(1), 283. https://doi.org/10.1186/s12888-0160962-y. 